\title{
The Effectiveness of Bank Aceh Syariah Conversion Decisions
}

\section{Zulfikar Bagus Pambuko}

Universitas Muhammadiyah Magelang, Indonesia

email: zulfikar.bp@ummgl.ac.id

\section{Diesyana Ajeng Pramesti}

Universitas Muhammadiyah Magelang, Indonesia

email: diesyana.ajeng@ummgl.ac.id

\begin{abstract}
Since 2008, Indonesia has had a particular policy for Islamic windows to spin off into full-fledged Islamic banks separate from their conventional parent if they meet the criteria. In the case of Bank Aceh Syariah, since Q3 2016, the spin-off has been done through a conversion mechanism from Bank Aceh to Bank Aceh Syariah. The study aims to analyze the effectiveness of conversion decisions in Bank Aceh Syariah. Non-parametric test with the Wilcoxon signedrank is used to analyze the banking performance due to the conversion. The performance indicators tested in the study are capital adequacy, liquidity risk, profitability, and management efficiency over Q2 2014 until Q3 2018. The results suggest that the conversion decision of Bank Aceh Syariah is effective in correcting the non-performing financing (NPF) ratio but declining the level of profitability through ROA, ROE, and NOM ratio. Thus, the spin-off decision through the conversion mechanism needs to forecast the future financial performance and the effort to fulfill sharia compliance.
\end{abstract}

Keywords: Conversion Decision; Islamic banks; Liquidity Risk; Profitability

\begin{abstract}
Abstrak: Sejak 2008, Indonesia memiliki kebijakan khusus bagi perbankan syariah yang mewajibkan UUS untuk melakukan spin-off menjadi BUS yang terpisah dari bank konvensional induknya jika telah memenuhi kriteria. Pada kasus Bank Aceh Syariah, sejak kuartal III 2016 telah dilakukan spin-off melalui mekanisme konversi dari Bank Aceh menjadi Bank Aceh Syariah. Tujuan penelitian ini adalah untuk menganalisis efektivitas keputusan konversi Bank Aceh Syariah. Pengujian non parametrik dengan uji Wilcoxon digunakan untuk menganalisis kinerja keuangan akibat konversi. Indikator kinerja yang diuji dalam studi ini adalah permodalan, risiko likuiditas, profitabilitas, dan efisiensi manajemen pada periode Q2 2014 hingga Q3 2018. Hasil penelitian ini menunjukkan bahwa keputusan konversi Bank Aceh Syariah efektif dalam memperbaiki rasio pembiayaan bermasalah (NPF), namun menurunkan tingkat profitabilitas melalui ROA, ROE, dan NOM. Dengan demikian, keputusan spin-off melalui konversi perlu mempertimbangkan capaian kinerja keuangan di masa mendatang, selain sebagai upaya pemenuhan kepatuhan terhadap syariah.
\end{abstract}

Kata Kunci: Keputusan Konversi; Bank Syariah; Risiko Likuiditas; Profitabilitas

Economica: Jurnal Ekonomi Islam - Volume 11, Nomor 1 (2020) 
Zulfikar Bagus Pambuko and Diesyana Ajeng Pramesti

\section{Introduction}

In the last two decades, the Islamic banking business has grown dramatically worldwide, especially in Indonesia. Islamic banking has a bright future as an infant industry, especially given Indonesia's vast Muslim population (Pambuko, Ichsan, and Anto 2018). In terms of total assets, thirdparty funds, and financing, Indonesian Islamic banking has witnessed positive growth over the last six years. From December 2012 to December 2018, the average growth of total assets, third-party funds, and financing was 18.76 percent, 18.40 percent, and 18.24 percent, respectively (see Table 1). In addition, as of December 2018, Indonesia had 14 full-fledged Islamic banks (hereafter BUS) and 20 Islamic windows (hereafter UUS), with 2,229 offices dispersed across the country. The number of full-fledged Islamic banks had increased dramatically since December 2008, when there were just 5 BUS and 27 UUS with 822 offices. However, this expansion was not accompanied by an increase in the Islamic banking market share, which stood at 5.92 percent of total national banking assets in December 2018. Thus, even though growth has been higher in recent years than in traditional banking, this result falls short of the target (Financial Service Authority 2019).

Table 1. Aggregate Islamic Banking Performance 2012-2018 (IDR Billion)

\begin{tabular}{lrrrrrrrr}
\hline & Dec-12 & Dec-13 & Dec-14 & Dec-15 & Dec-16 & Dec-17 & Dec-18 & $\begin{array}{c}\text { Average } \\
\text { Growth }\end{array}$ \\
\hline Asset & 195,02 & 242,28 & 272,34 & 296,26 & 356,50 & 424,18 & 454,25 & \\
Growth (YoY) & $\mathbf{3 4 . 0 6}$ & $\mathbf{2 4 . 2 3}$ & $\mathbf{1 2 . 4 1}$ & $\mathbf{8 . 7 8}$ & $\mathbf{2 0 . 3 3}$ & $\mathbf{1 8 . 9 8}$ & $\mathbf{1 2 . 5 3}$ & $\mathbf{1 8 . 7 6}$ \\
\hline $\begin{array}{l}\text { Third Party } \\
\text { Funds }\end{array}$ & 147,51 & 183,53 & 217,86 & 231,18 & 279,34 & 334,89 & 355,92 & \\
Growth (YoY) & $\mathbf{2 7 . 8 1}$ & $\mathbf{2 4 . 4 2}$ & $\mathbf{1 8 . 7 0}$ & $\mathbf{6 . 1 1}$ & $\mathbf{2 0 . 8 3}$ & $\mathbf{1 9 . 8 9}$ & $\mathbf{1 1 . 0 3}$ & $\mathbf{1 8 . 4 0}$ \\
\hline Financing & 147,50 & 184,12 & 200,18 & 213,99 & 249,09 & 286,91 & 313,99 & $\mathbf{1 8 9 . 2 4}$ \\
Growth (YoY) & $\mathbf{4 3 . 6 9}$ & $\mathbf{2 4 . 8 2}$ & $\mathbf{8 . 7 2}$ & $\mathbf{6 . 9 0}$ & $\mathbf{1 6 . 4 0}$ & $\mathbf{1 5 . 1 9}$ & $\mathbf{1 1 . 9 9}$ & $\mathbf{1 8 . 9 2}$ \\
\hline Market Share & 4.6 & 4.9 & 4.9 & 4.9 & 5.3 & 5.7 & 5.92 & \\
\hline
\end{tabular}

Source: Islamic Banking Statistics (Financial Service Authority 2019) 
The government has taken notice of the growth and has responded with policies to assist it. One of them is the enactment of Act Number 21/2008, which deals with Islamic banking. The essential strategic approach of the Act to encourage the development of Islamic banking is the spin-off policy. The policy requires UUS to spin-off into BUS 15 years after the Act takes effect or ends in 2023 and/or has assets equal to at least $50 \%$ of the parent conventional bank's assets (Republic of Indonesia 2008). As a result, this spinoff policy is one of the most critical topics in Islamic banking law, and it is unique to Indonesia (Al Arif et al, 2018).

Previous researchers have widely studied the phenomenon of this spinoff policy. The spin-off policy hurts the performance of conventional banks by decreasing profitability and increasing operational inefficiency (Poerwokoesoemo 2016). For Islamic banking, the spin-off policy has no impact on financing growth, asset growth, and profitability (Al Arif 2015a; 2015b; Al Arif and Dewanti 2017; Sihombing and Yahya 2016). However, Hamid (2015) has different findings where the spin-off policy impacts the level of profitability of Islamic banking. The spin-off policy also reduces the market share of Islamic banking (Al Arif 2017). Efficiency also decreased after the spin-off (Al Arif, Haribowo, and Suherlan 2018). Apart from that, the spinoff policy increased the number of third-party funds (Al Arif 2014; 2018).

Furthermore, several findings indicate that the spin-off policy is not ready to be applied to the Islamic banking industry in Indonesia. Arif et al. (2018) evaluated and predicted that Islamic windows are unlikely to meet the criteria in 2023 or 15 years after the Act is enacted, but the spin-off must still be implemented. Based on all the previous findings, this study attempts to elaborate on the impact of the spin-off policy on the achievement of financial performance, especially Islamic banks formed through the conversion process. The conventional bank that carries out the conversion process to become full-fledged Islamic banking is Bank Aceh Syariah. 
The conversion process of Bank Aceh Syariah in 2016 was not an easy stage. The UUS Bank Aceh spin-off effort has been planned since 2013 and will be realized in 2016. Even in 2014, the effect to establish full-fledged Islamic banking was supported by the issuance of Aceh Qanun Number 9/2014 concerning the Establishment of Bank Aceh Syariah and a capital injection of 500 billion rupiahs from the Aceh Government (Rongiyati 2015). Furthermore, in 2016 Aceh Qanun Number 5/2016 was issued regarding the Revocation of Aceh Qanun Number 9/2014 concerning the Establishment of Bank Aceh Syariah. This policy was decided to accelerate the conversion process from the conventional system to sharia in a kaffah manner. After that, the Aceh government again issued Aceh Qanun Number 11/2018 to strengthen the enforcement of Islamic law, in particular by requiring all financial institutions operating in Aceh to use sharia principles.

Therefore, this study can be used to evaluate spin-off policies, particularly with the conversion mechanism for individual banking and its contribution to the Islamic banking industry in Indonesia. So that, every logical consequence on the financial aspects related to this can be a reference for individual banking and Financial Service Authority (FSA) to implement or not implement the spin-off policy until 2023.

Based on the above description, this study aims to analyze the effectiveness of the conversion decision of Bank Aceh Syariah in terms of various financial aspects. To achieve the goal of this study, different tests were carried out on the financial performance of Bank Aceh Syariah in the period before and after the conversion was carried out.

\section{Literature review}

The literature review in the study consists of two parts, namely the spinoff concept and previous studies on spin-offs.

The first part, the spin-off is a new institution regulated in the Limited Liability Company Law and the Islamic Banking Law. According to the Limited 
Liability Company Law Number 40/2007 article 1 number 12, spin-off is defined as a legal action carried out by a company to separate its business unit which results in all assets and liabilities of the company being transferred by law to one or more companies or part of the company's assets and liabilities being transferred by law to another company, one or more companies (Republic of Indonesia 2007). Then, according to the Islamic Banking Law Number 21/2008 article 1 number 32, the spin-off is defined as separating the business unit from one bank into two or more business entities (Republic of Indonesia 2008).

The implementation of the spin-off policy has several strategic reasons, including 1) to accelerate the growth of the Islamic banking industry, 2) to improve the performance of Islamic banking, 3) to increase the independence of Islamic banking in managing resources, and 4) to increase compliance with sharia (Umam 2010; Al Arif 2018). Furthermore, efforts to encourage a spinoff policy were responded to by Bank Indonesia by issuing PBI No. 12/21/PBI/2010 concerning bank business plans in which banks are required to plan the spin-offs on UUS owned by conventional banks. Besides, PBI No. 14/8/PBI/2012 concerning share ownership in commercial banks allows shareholders in the spinning-off Islamic bank to own shares in excess of the maximum share ownership limit (Haribowo 2017).

The spin-off policy in Islamic banking has just been implemented in Indonesia, but the spin-off concept can be used as a reference in other industries. Elfring and Foss (1997) explain that there are two types of spinoffs, namely: first, related to the parent company, where the parent company, for whatever reason, is unable to take advantage of the future opportunitiessecond, related to organizational units as individuals. This second type is the most widely practiced, where the subsidiary is not the same as the parent company. This second category is included in the spin-off of sharia business units in Indonesian commercial banks. 
After Law Number 21/2008 was passed, a new trend emerged in the formation of Islamic banks through four spin-off methods. First, commercial banks that already have UUS acquire relatively small banks, then convert them to sharia-based, then release and merge their UUS into BUS. Second, commercial banks spin off their UUS to become BUS. Third, commercial banks that do not have UUS acquire other commercial banks and turn them into BUS. Fourth, commercial banks convert themselves into BUS (Al Arif and Dewanti 2017; Al Arif 2015a). Of the 11 Islamic banks that implemented the spin-off policy after the law was enacted, 4 of them used the first scheme, 3 BUS used the second scheme, 2 BUS used the third scheme, and 2 BUS used the fourth scheme (Hilman 2018; Financial Service Authority 2019).

In the second part, previous studies on Islamic banking spin-offs have been carried out by several researchers. Based on the previous explanation, spin-offs can be carried out by several methods, but the differences in these methods have no impact on the performance of spin-off Islamic banks (Al Arif et al., 2017). In fact, within fifteen years after the issuance of the Act or in 2023, there will be no Islamic bank that can reach $50 \%$ of their parent's assets. In addition, based on the simulation, high asset growth is required to achieve the parent bank's market share assets (Al Arif et al., 2018).

For conventional banks that release UUS to become BUS, the spin-off impacts several conventional bank performances, such as increasing the NPL, OER, CAR, and LDR ratio; and decreasing ROA ratio (Poerwokoesoemo 2016). However, for Islamic banks, the spin-off decision has been shown to significantly increase third-party funds (TPF) (Al Arif 2014; 2018). This is reinforced by Siswantoro (2014) who revealed that capital injection and TPF followed by effective management could encourage the growth of spin-off Islamic banks. Although from a different perspective, several studies (Siswantoro 2008; Al Arif et al. 2017) reveal that spin-offs have no impact on increasing TPF. 
Based on the asset growth and financing, the spin-off decision has not been able to have a significant impact on these two financial performances (Al Arif 2015a; 2015b; Siswantoro 2008). Based on the market share level, the spin-off decision also made the market share ratio of Islamic banks lower (Al Arif 2017). From a different aspect, Pambuko, Usman, and Andriyani (2019) revealed that the spin-off decision was able to increase the productivity of Islamic banks in managing their social funds. Changes in technology support this.

Furthermore, Hamid (2015) revealed that the spin-off decision significantly affected the level of profitability in the Islamic banking industry in Indonesia. This is different from the findings of Sihombing and Yahya (2016) and Al Arif and Dewanti (2017), which state that the spin-off policy does not affect the profitability of the spin-off Islamic banks. This is reinforced by the opinion of Hilman (2018) that the growth rate of BUS business activities is better than UUS. Still, in terms of profitability and efficiency, UUS is better than BUS. In addition, Al Arif, Haribowo, and Suherlan (2018) added that the spin-off decision made Islamic bank operations more inefficient. However, Pambuko (2019) revealed that the spin-off decision made Islamic bank operations more efficient because they could generate better profits. In fact, Sarifudin dan Faturohman (2017) research found that the average efficiency of BRI Syariah, BNI Syariah, and BJB Syariah had improved after the spin-off.

Based on a review of all previous studies, this study is focused on developing a study on the spin-off policy mandated by Law Number 21/ 2008 concerning Islamic Banking and its impact on financial performances. The financial performance is in the form of capital adequacy (CAR), liquidity risk (NPF, FDR), profitability (ROA, ROE, NOM), and management efficiency (OER) for Islamic banking formed through the conversion process. The second reason is that the study on conversion impact at Bank Aceh Syariah has never been done before.

Economica: Jurnal Ekonomi Islam - Volume 11, Nomor 1 (2020) https://journal.walisongo.ac.id/index.php/economica 


\section{Methods}

This study used secondary data in the form of a quarterly time series. The data was obtained from quarterly financial reports from the Bank Aceh Syariah's website from the second quarter (Q2) of 2014 to the third quarter (Q3) of 2018. The period before conversion was from Q2 2014 to Q2 2016, while the period after the conversion was from Q3 2016 to Q3 2018. Variables used in this study, namely Capital Adequacy Ratio (CAR), Non-Performing Financing (NPF), Return on Assets (ROA), Return on Equity (ROE), Net Operating Margin (NOM), Operational Efficiency Ratio (OER), and Financing to Deposit Ratio (FDR). The seven variables represent financial performance in profitability, management efficiency, liquidity risk, and capital adequacy. The operational definition of each variable is presented in Table 2.

This study used a quantitative method by Wilcoxon test. The test was used to analyze the results of paired observations of two data indicating a difference. In the context of this study, the Wilcoxon test was used to examine the differences in the financial performance of Bank Aceh Syariah before and after the conversion process. This test is better than the sign test. This analysis was used because the data was not normally distributed and was in ratio data. The following was the formula for the Wilcoxon test.

Table 2. Operational Definition of Variables

\begin{tabular}{clc}
\hline Variable & Operational Definition & Unit \\
\hline CAR & Capital adequacy ratio that compares capital to total assets & $\%$ \\
NPF & Ratio of non-performing financing to total financing & $\%$ \\
FDR & Ratio of financing to third party funds & $\%$ \\
ROA & Ratio of profit before tax to total assets on average & $\%$ \\
ROE & Ratio of profit after tax to total capital average & $\%$ \\
NOM & Profitability ratio which is the difference between & $\%$ \\
& operating income after profit sharing with operating & \\
& expenses divided by average productive assets & $\%$ \\
\hline
\end{tabular}




$$
Z=\frac{T-\left[\frac{N(N+1)}{4}\right]}{\sqrt{\frac{N(N+1)(2 N+1)}{24}}}
$$

Wherein:

$\mathrm{N}$ : A lot of data that changes after being given different treatment

$\mathrm{T}$ : Less number of rankings based on the sign

The hypothesis test used in the test is as follows.

$\mathrm{H}_{0}: \mathrm{d}=0 \rightarrow$ there is no difference between before and after conversion decision

$\mathrm{H}_{1}: \mathrm{d} \neq 0 \rightarrow$ there is a difference between before and after conversion decision

\section{Result and discussion}

The results and discussion in this study are presented in several sections. Among them are descriptive analysis, difference analysis, and discussion.

\section{Descriptive analysis}

The results of the descriptive analysis in the form of data before and after conversion decision for financial performance variables (CAR, NPF, FDR, ROA, ROE, NOM, and OER) at Bank Aceh Syariah analyzed in this study are presented in table 3.

Economica: Jurnal Ekonomi Islam - Volume 11, Nomor 1 (2020) https://journal.walisongo.ac.id/index.php/economica 
Zulfikar Bagus Pambuko and Diesyana Ajeng Pramesti

Table 3. Descriptive Analysis of Research Variables

\begin{tabular}{lrrrr}
\hline Variabel & Mean & Std. Deviation & Min. & Max. \\
\hline CAR_Bef & 18.93 & 2.24 & 16.23 & 21.92 \\
CAR_Aft & 20.86 & 1.20 & 18.66 & 22.59 \\
\hline NPF_Bef & 2.55 & 0.26 & 2.06 & 2.96 \\
NPF_Aft & 1.55 & 0.18 & 1.38 & 1.97 \\
\hline LDR_Bef & 75.09 & 9.25 & 61.47 & 92.38 \\
FDR_Aft & 69.65 & 9.20 & 60.02 & 84.59 \\
\hline ROA_Bef & 3.26 & 0.60 & 2.49 & 4.23 \\
ROA_Aft & 2.17 & 1.01 & 0.41 & 3.40 \\
\hline ROE_Bef & 24.36 & 3.07 & 20.79 & 30.48 \\
ROE_Aft & 17.88 & 7.66 & 3.47 & 23.28 \\
\hline NIM_Bef & 7.33 & 0.21 & 6.96 & 7.64 \\
NOM_Aft & 0.72 & 2.49 & -4.76 & 2.91 \\
\hline OER_Bef & 71.62 & 5.50 & 62.37 & 78.00 \\
OER_Aft & 79.98 & 8.40 & 69.69 & 94.43 \\
\hline
\end{tabular}

Source: Processed research data

Based on Table 3, it can be concluded that there was a change in the financial performance of Bank Aceh Syariah after the conversion was carried out, both positive and negative. First, the capital adequacy ratio (CAR) after conversion is higher than before $(20.86 \%>18.93 \%)$. Regarding the minimum and maximum values for both periods, the CAR ratio has also met the minimum standard, which is above $8 \%$.

Second, the ratio of non-performing financing (NPF) after conversion is smaller than before $(1.55 \%>2.55 \%)$. This means that non-performing financing at Bank Aceh Syariah decreased after the decision. The NPF value is still in a safe position in terms of the minimum and maximum values in both periods, which is below $5 \%$. Third, the ratio of financing to deposit ratio (FDR) after conversion is lower than before $(69.65 \%<75.09 \%)$. This shows that the amount of financing disbursed from third-party funds decreases when converting to full-fledged Islamic banks. Fourth, the ratio of return on assets (ROA) after the conversion is smaller than before $(2.17 \%<3.26 \%)$. Thus, the 
ability of Bank Aceh Syariah to earn a profit from the assets is decreasing after the conversion decision is implemented.

Fifth, the return on equity (ROE) after conversion is also smaller than before $(17.88 \%<24.36 \%)$. In line with the ROA conditions, the ROE ratio, which reflects the ability of Islamic banks to earn profits from their own capital, also decreased after the conversion decision. Sixth, the Net Operating Margin (NOM) after the conversion is smaller than before $(0.72 \%<7.33 \%)$. This condition shows that the profitability of Bank Aceh Syariah is decreasing, although it is still profitable when compared to when operating conventionally. Seventh, the operational efficiency ratio (OER) after the conversion is more significant than before (79.98\% > 71.62\%). This means that Bank Aceh, after becoming a full-fledged Islamic bank in its operations, becomes more inefficient.

\section{Difference analysis}

The results of the Wilcoxon test to find out whether there are differences in financial performance before and after the conversion decision of Bank Aceh Syariah are presented in Table 4.

Table 4. Wilcoxon Test Results

\begin{tabular}{lcr}
\hline Variabel & Z & Asymp. Sig. (2-tailed) \\
\hline CAR_Aft - CAR_Bef & $-1.955^{\mathrm{b}}$ & 0.051 \\
NPF_Aft - NPF_Bef & $-2.666^{\mathrm{c}}$ & $\mathbf{0 . 0 0 8}$ \\
FDR_Aft - LDR_Bef & $-1.481^{\mathrm{c}}$ & 0.139 \\
ROA_Aft - ROA_Bef & $-2.192^{\mathrm{c}}$ & $\mathbf{0 . 0 2 8}$ \\
ROE_Aft - ROE_Bef & $-2.073^{\mathrm{c}}$ & $\mathbf{0 . 0 3 8}$ \\
NOM_Aft - NIM_Bef & $-2.666^{\mathrm{c}}$ & $\mathbf{0 . 0 0 8}$ \\
OER_Aft - OER_Bef & $-1.955^{\mathrm{b}}$ & 0.051 \\
\hline a. Wilcoxon Signed Ranks Test & & \\
b. Based on negative ranks & & \\
c. Based on positive ranks & & \\
\hline
\end{tabular}

Source: Processed research data

Economica: Jurnal Ekonomi Islam - Volume 11, Nomor 1 (2020) https://journal.walisongo.ac.id/index.php/economica 
Based on Table 4, it is known that the three financial performance variables do not show significant differences between before and after the conversion decision. In comparison, the other four variables show significant differences. The following is a description of each variable.

First, the Asymp. Sig. CAR value is 0.051 and greater than 0.05 (5\%), which indicates that $\mathrm{H} 0$ is accepted and $\mathrm{H} 1$ is rejected. This means that there is no significant difference between before and after the conversion decision of Bank Aceh Syariah in the CAR ratio. Second, the calculated $Z$ value marked with the letter (b) or 'based on negative rank' also shows that the CAR ratio has increased after the conversion decision, although there was no significant difference.

Second, the Asymp. Sig. value of NPF is 0.008 and smaller than 0.05 (5\%), which indicates that $\mathrm{H} 0$ is rejected and $\mathrm{H} 1$ is accepted. This means that there is a significant difference between before and after the conversion decision of Bank Aceh Syariah on the NPF ratio. Furthermore, the calculated $\mathrm{Z}$ value marked with the letter (c) or 'based on positive rank' also indicates that the NPF ratio has decreased after the conversion decision.

Third, the Asymp. Sig. value of FDR is 0.139 and greater than 0.05 (5\%), which indicates that $\mathrm{H} 0$ is accepted and $\mathrm{H} 1$ is rejected. This means that there is no significant difference between before and after the conversion decision of Bank Aceh Syariah on the FDR ratio. Furthermore, the calculated $Z$ value marked with the letter (c) or 'based on positive rank' also shows that the FDR ratio decreased after the conversion decision, although there was no significant difference.

Fourth, the Asymp. Sig. value of ROA is 0.028 and less than 0.05 (5\%), which indicates that $\mathrm{H} 0$ is rejected and $\mathrm{H} 1$ is accepted. This means that there is a significant difference between before and after the conversion decision of Bank Aceh Syariah on the ROA ratio. The calculated $\mathrm{Z}$ value marked with the 
letter (c) or 'based on positive rank' also indicates that the ROA ratio has decreased after the conversion decision.

Fifth, the Asymp. Sig. value of ROE is 0.038 and smaller than 0.05 (5\%), which indicates that $\mathrm{H} 0$ is rejected and $\mathrm{H} 1$ is accepted. This means that there is a significant difference between before and after the conversion decision of Bank Aceh Syariah on the ROE ratio. Furthermore, the calculated $\mathrm{Z}$ value marked with the letter (c) or 'based on positive rank' also shows that the ROE ratio has decreased after the conversion decision.

Sixth, the Asymp. Sig. value of NOM is 0.008 and smaller than 0.05 (5\%) which indicates that $\mathrm{H} 0$ is rejected and $\mathrm{H} 1$ is accepted. This means that there is a significant difference between before and after the conversion decision of Bank Aceh Syariah in the NOM ratio. The calculated $Z$ value marked with the letter (c) or 'based on positive rank' also indicates that the NOM ratio has decreased after the conversion decision.

Seventh, the Asymp. Sig. value of OER is 0.051 and greater than 0.05 (5\%), which indicates that $\mathrm{H} 0$ is accepted and $\mathrm{H} 1$ is rejected. This means that there is no significant difference between before and after the conversion decision of Bank Aceh Syariah on the OER. The calculated $\mathrm{Z}$ value marked with the letter (b) or 'based on negative rank' also shows that the OER has increased after the conversion decision, although there was no significant difference.

\section{Discussion}

A study on the impact of the conversion decision of Bank Aceh Syariah on financial performance is carried out by comparing the financial conditions before and after the decision. The period used before implementing the decision is from Q2 2014 to Q2 2016 as Bank Aceh commercial bank, while after the decision is from Q3 2016 to Q3 2018 as Bank Aceh Syariah.

First, the impact of the conversion decision on capital adequacy (CAR) which is explained there is no significant difference after conversion even 
though the nominal of CAR increases. These results do not support Poerwokoesoemo (2016) findings who found differences between CAR before and after the spin-off at Bank Bukopin, Bank BRI, Bank Jabar, and Banten Bank BNI. This condition is understandable considering that conversion is shifting the operating model from conventional to sharia principle following POJK 64/2016. Therefore, it is also possible that the capital structure will not change much even though in the case of Bank Aceh Syariah, there was an injection of capital by the Aceh Government. Bank Aceh Syariah is currently the fifth largest Islamic bank in Indonesia under BRI Syariah, BSM, BNI Syariah, and Bank Muamalat. The existence of Bank Aceh Syariah as a new BUS in 2016 also supports the acceleration of the growth of the Islamic banking industry in Indonesia (Al Arif 2018; Umam 2010). This can be seen from its contribution, which increased the market share of Islamic banking above $5 \%$ at the end of 2016 and continues to grow until now.

Second, the impact of conversion decision on liquidity risk as proxied by NPF shows a significant difference after conversion. The number of nonperforming financing faced by Bank Aceh Syariah is known to decrease after the conversion. This indicates that the ability of Bank Aceh Syariah in controlling liquidity risk in the form of controlling non-performing financing is getting better after the implementation of the sharia principle in its operations. These results support Poerwokoesoemo (2016) findings, which explained the correction in the NPF ratio after the spin-off. The NPF ratio that continues to get better is also supported by the composition of financing, which is dominated by Murabahah contracts which are low risk and generate fixed income. Figure 1 shows the decrease in NPF at Bank Aceh Syariah after the conversion decision. 
Figure 1. Comparison of NPF Ratio

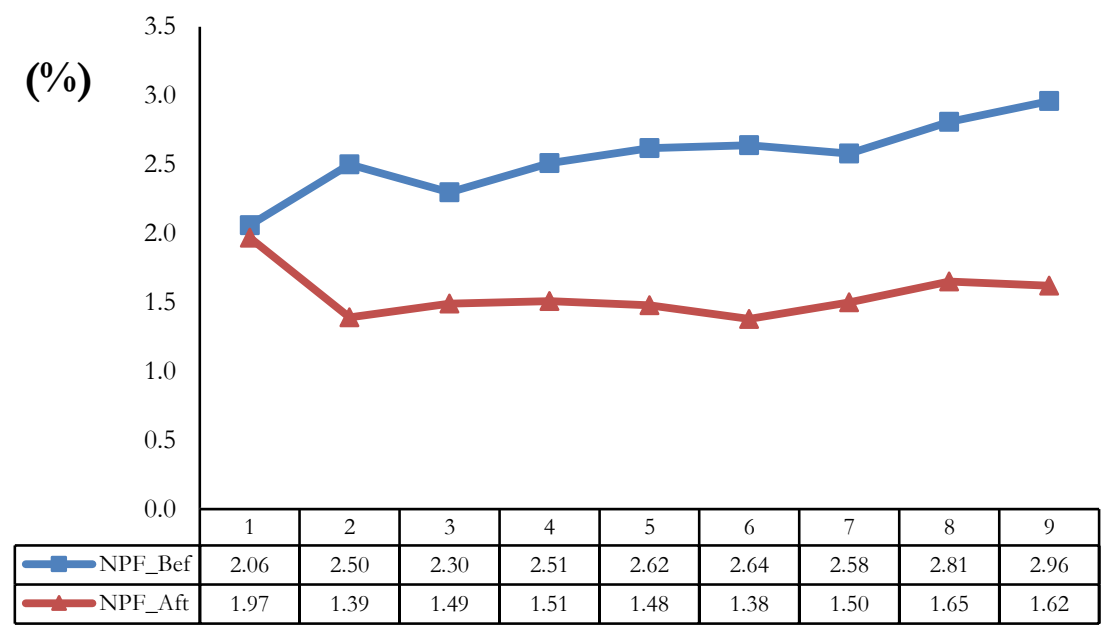

Afterward, the impact of conversion decision on liquidity risk as proxied by FDR is explained that there is no significant difference after conversion. Even the amount of financing disbursed from third-party funds also decreased after the conversion process. These results support several previous findings (Al Arif 2015a; 2015b; Al Arif and Dewanti 2017; Sihombing and Yahya 2016) which revealed that the spin-off policy had no impact on financing growth. This condition is also evidenced by the growth of financing after conversion, which is lower than before conversion $(0.73 \%<1.80 \%)$ even though it always increases if viewed from the nominal financing throughout the observation period. Furthermore, in terms of the nominal TPF managed by Bank Aceh Syariah throughout the observation period, the results of this study also support the findings of Arif $(2014,2018)$, which reveals that spin-offs can increase TPF. Still, these results do not support the conclusions of Siswantoro (2008). On the other hand, the growth of TPF after conversion was also not better than before conversion even though it was in a positive growth position $(3.60 \%<5.82 \%)$.

Economica: Jurnal Ekonomi Islam - Volume 11, Nomor 1 (2020) https://journal.walisongo.ac.id/index.php/economica 
Figure 2. Growth in Financing and Third-Party Funds (IDR Million)

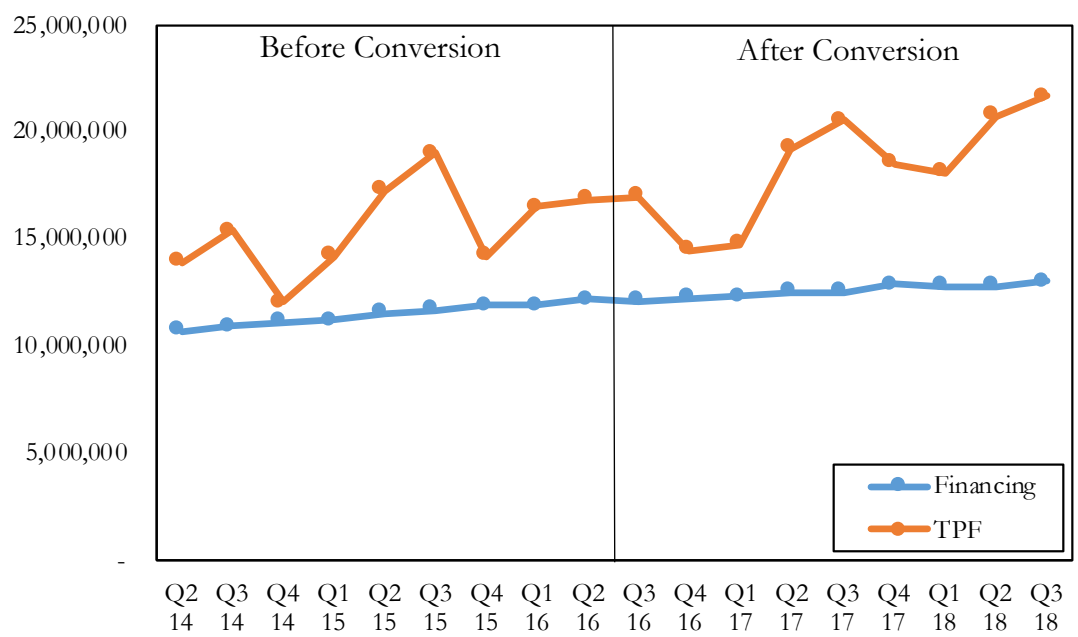

Thus, the downward trend in the FDR ratio was caused by a slowdown in financing growth that was not commensurate with the increase in the number of TPF that were collected. Even this amount has not been met the criteria set by the authority that Islamic banking financing should be in the range of 7892\% (See Figure 2 for more detail).

Third, the impact of conversion decisions on profitability as proxied by ROA shows a significant difference after conversion. The difference shows a decrease in profit before tax from total assets after conversion. These results support the findings of Hamid (2015), which revealed that spin-offs affect the level of profitability. The downward trend of ROA after conversion is also in line with Poerwokoesoemo (2016) and Hilman (2018) findings. This trend is caused by the adjustment of conventional assets to Islamic bank, so that sharia business processes cannot be applied directly after conversion. Figure 3 explains that the initial two periods after conversion were only able to generate profits below one percent due to a decrease in the amount of financing disbursed, but the number of assets continued to increase. Other 
than that, these results do not support several findings (Siswantoro 2008; Sihombing and Yahya 2016; Al Arif and Dewanti 2017), revealing that the spin-off policy has no impact on the level of profitability of Islamic banking.

Then, the impact of conversion decision on profitability as proxied by ROE also shows a significant difference after conversion. The difference indicates a decrease in generating after-tax profit from the total paid-in capital after conversion. In line with the findings on the ROA ratio, these results also support the conclusions of Hamid (2015), Poerwokoesoemo (2016), and Hilman (2018). As explained in the discussion of ROA, Figure 4 is said that the ROE ratio in the two initial periods after conversion is decreasing. After that, there was an improvement in performance until the end of the observation period. The improvement was at the same level as the achievement when operating conventionally.

Figure 3. Comparison of ROA Ratio

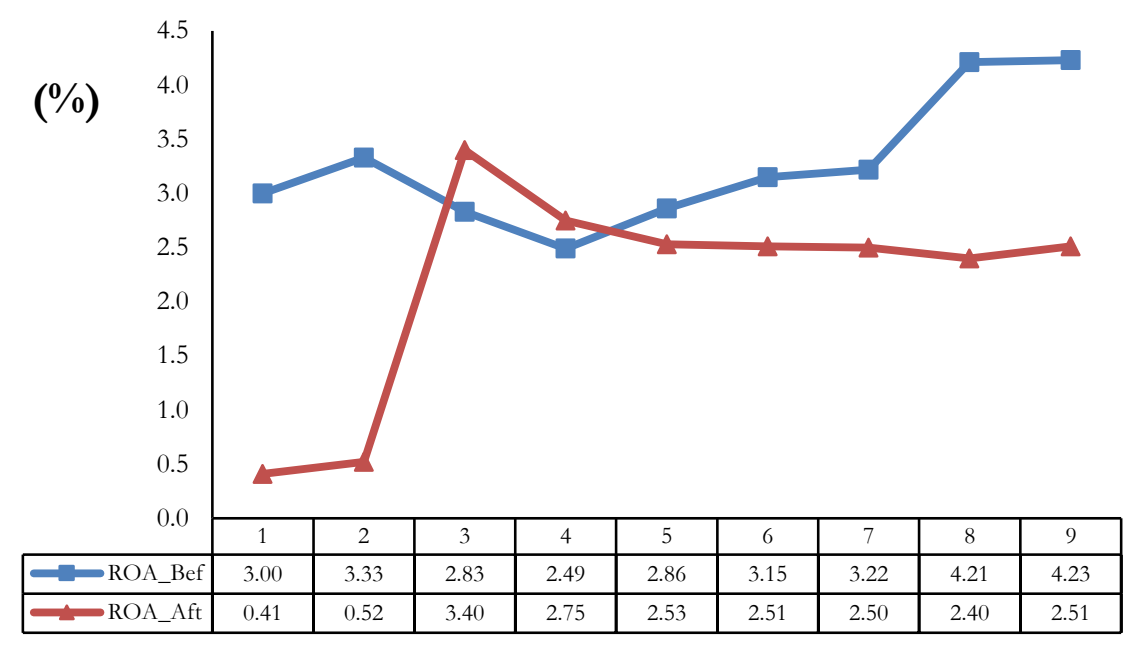

Economica: Jurnal Ekonomi Islam - Volume 11, Nomor 1 (2020) https://journal.walisongo.ac.id/index.php/economica 
Zulfikar Bagus Pambuko and Diesyana Ajeng Pramesti

Figure 4. Comparison of ROE Ratio

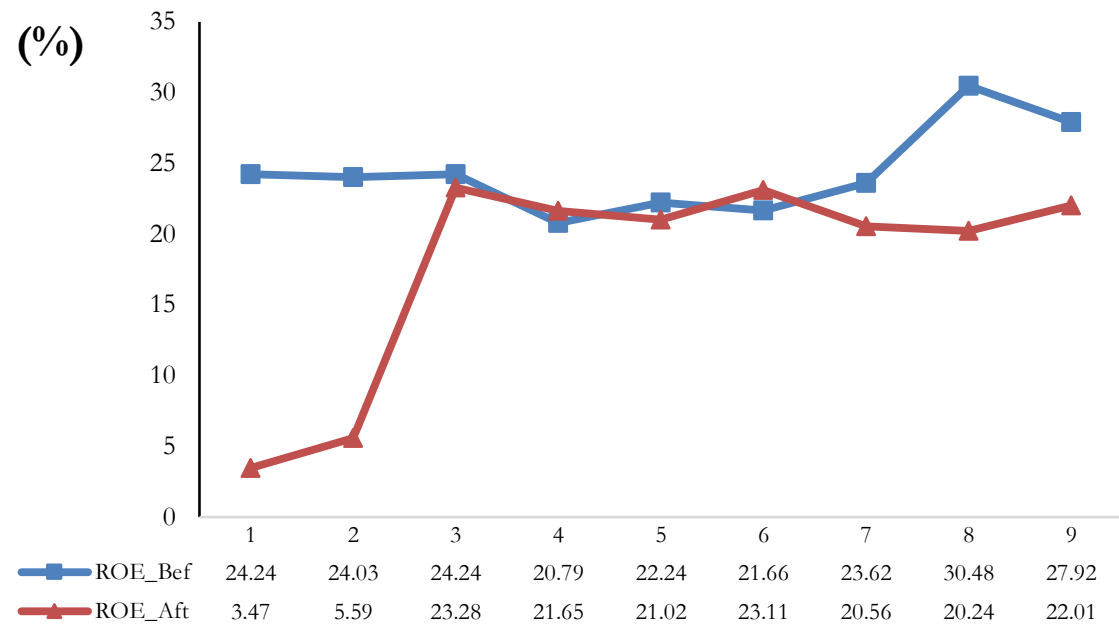

Figure 5. Comparison of NOM ratio

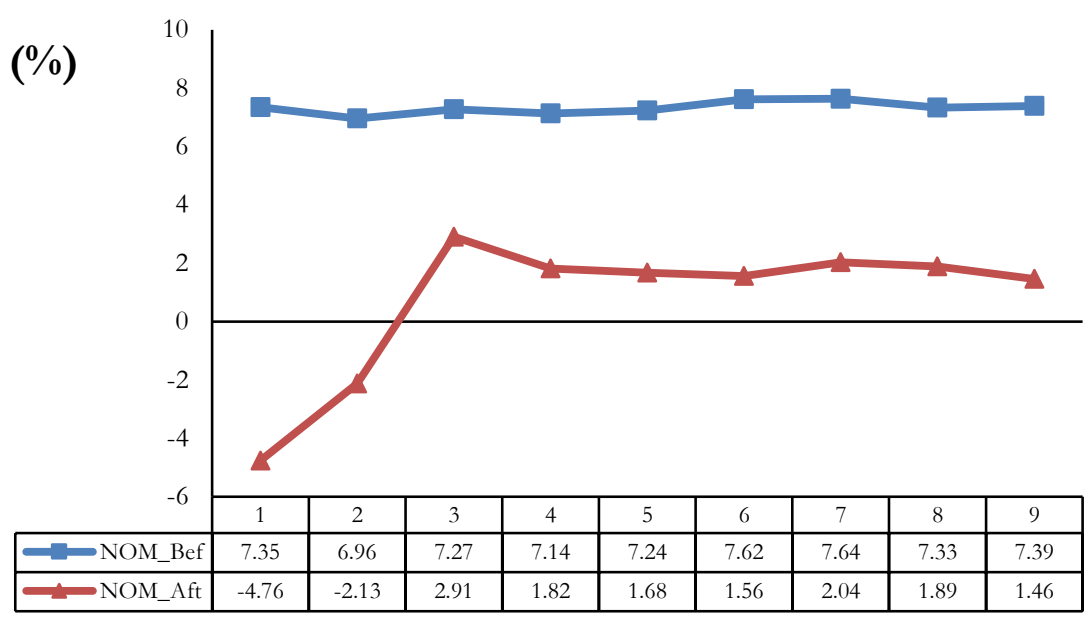


Moreover, the impact of conversion decisions on profitability as proxied by NOM also significantly differs after conversion. The difference shows a decrease in the profit from the average earning assets managed after the conversion. This condition is in line with the findings on the ratio of ROA and ROE and supports the findings of Hamid (2015); Poerwokoesoemo (2016); and Hilman (2018). The decrease was caused by conditions identical to the findings in the ROA and ROE ratios. Even in the first two quarters after implementing the conversion decision, Bank Aceh Syariah's net operating margin (NOM) ratio was negative. After that, efforts were continued to improve so that the NOM ratio became positive, although the amount was not comparable to the net interest margin (NIM) level when using the conventional system (see Figure 5).

Fourth, the impact of the conversion policy on management efficiency has no significant difference after conversion, although management efficiency worsens with an increase in the average OER ratio. The results do not support Sarifudin and Faturohman (2017) and Pambuko (2019), which revealed that the efficiency of Islamic banks after the spin-off became better. However, these results support several findings (Poerwokoesoemo 2016; Al Arif, Haribowo,

Figure 6. Comparison of OER

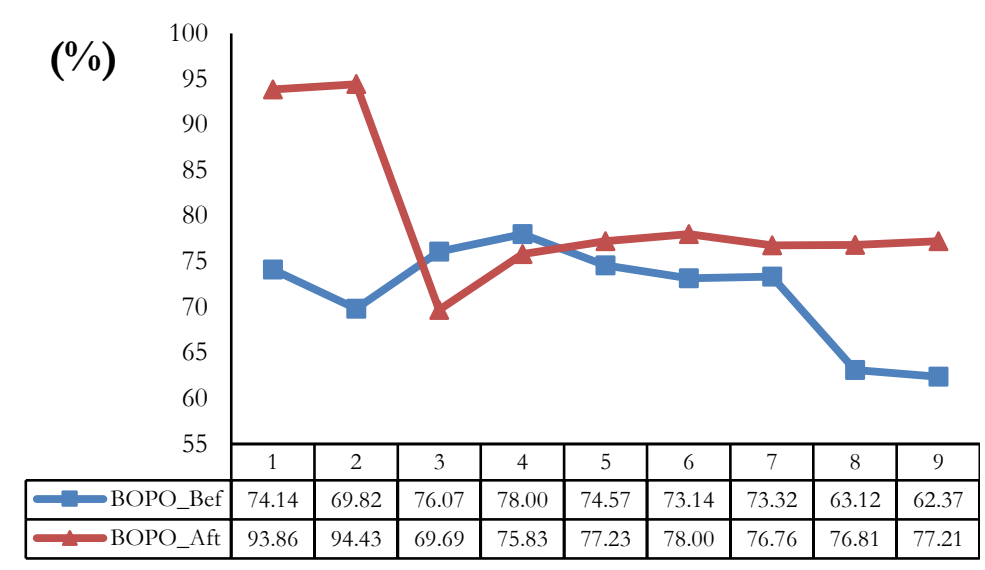

Economica: Jurnal Ekonomi Islam - Volume 11, Nomor 1 (2020) https://journal.walisongo.ac.id/index.php/economica 
and Suherlan 2018; Hilman 2018), which declared that the efficiency of Islamic banks decreased after the spin-off. As described in the previous discussion, the financial performance of Bank Aceh Syariah in the two quarters after the conversion was weak. This also happened to the ability of management efficiency. In the two periods, the OER ratio was above $90 \%$ and continued to be improved until the end of the observation period, below the maximum OER limit (below 85\%). Although it does not significantly impact management efficiency, the OER ratio is still in a good position (see Figure 6).

\section{Conclusion}

Based on the results, the financial performance of Bank Aceh Syariah after conversion resulted in varying findings. First, financial performance related to capital adequacy in CAR concluded that there was no change in performance after conversion despite an increase in the ratio. Second, financial performance related to liquidity risk in NPF and FDR concluded that there was an improvement in the NPF ratio and a decrease in the FDR ratio. Third, financial performance in the form of profitability as measured by ROA, ROE, and NOM concludes identical findings, as the conversion decision cannot increase the bank's performance to generate more profits. Fourth, financial performance related to management efficiency as measured by OER concluded that there is no improvement in efficiency after conversion.

The conclusions have several implications for the development of Islamic banking in Indonesia. First, the business plan of a bank that will carry out a spin-off needs to get more attention from the Financial Services Authority (FSA) as policymakers. Only solid and well-performing institutions are prioritized to implement the spin-off policy immediately. Second, the conversion model has a positive impact on controlling financing risk, so that banking focus needs to be directed to increase profitability and efficiency with appropriate policy formulations, such as creating innovative Islamic banking products that meet the community's needs. 
The limitation of this study is the focus of researchers on Islamic banks which are generated through the conversion process. Future research needs to compare the achievements of several spin-off models to enrich the results and produce more comprehensive policy recommendations. With this breakthrough, the influence of the spin-off policy on Islamic banking performance will be more quantifiable.

\section{References}

Arif, M.Nur Rianto Al. 2014. "Spin-off and Its Impact on the Third Party Funds of Indonesian Islamic Banking Industry." Economic Journal of Emerging Markets 6 (1): 50-55.

- _ . 2015a. "Impact of Spin-Off Policy on The Asset Growth on Indonesian Islamic Banking Industry." Journal of Islamic Economics, Banking and Finance 11 (4): 41-52. https://doi.org/10.12816/0024787.

- - 2. 2015b. "The Effect of Spin-Off Policy on Financing Growth in Indonesian Islamic Banking Industry." Al-Ulum 15 (1): 173-84.

- _ . 2017. "Spin-Off and Market Share in the Indonesian Islamic Banking Industry: A Difference in Difference Analysis." Management and Marketing 12 (4): 540-51. https://doi.org/10.1515/mmcks-2017-0032.

__- 2018. "Does the Spin-Off Policy Can Accelerate the Deposit Funds in the Indonesian Islamic Banking Industry?" Journal of Business and Retail Management Research 13 (1): 171-78.

Arif, M.Nur Rianto Al, and Endah Putri Dewanti. 2017. "Metode Spin-Off Dan Tingkat Profitabilitas: Studi Pada Bank Umum Syariah Hasil Spin-Off." Iqtishadia: Jurnal Kajian Ekonomi Dan Bisnis Islam 10 (1): 23-43. https://doi.org/10.21043/iqtishadia.v10i1.2316.

Arif, M.Nur Rianto Al, Ismawati Haribowo, and Ade Suherlan. 2018. "Spin-Off Policy and Efficiency in the Indonesian Islamic Banking Industry." Banks $\begin{array}{lllll}\text { and } & \text { Bank } & \text { Systems } & 13 & \text { (1): }\end{array}$ https://doi.org/10.21511/bbs.13(1).2018.01.

Arif, M.Nur Rianto Al, Nachrowi D. Nachrowi, Mustafa Edwin Nasution, and T. M. Zakir Mahmud. 2017. "The Islamic Banking Spin-Off: Lessons From Indonesian Islamic Banking Experiences." Journal of King Abdulaziz 
Zulfikar Bagus Pambuko and Diesyana Ajeng Pramesti

University, $\quad$ Islamic Economics $30 \quad$ (2): $117-33$. https://doi.org/10.4197/Islec.30-2.11.

- — . 2018. "Evaluation of the Spinoffs Criteria: A Lesson from The Indonesian Islamic Banking Industry." Iqtishadia: Jurnal Kajian Ekonomi Dan Bisnis Islam 11 (1): 87-104. https://doi.org/10.21043/iqtishadia.v10i2.2863.

Elfring, Tom, and Nicolai J. Foss. 1997. "Corporate Renewal Through Internal Venturing and Spin-Offs: Perspectives from Organizational Economics." WP 97-7. Copenhagen.

Financial Service Authority. 2019. "Sharia Banking Statistics September 2019." Jakarta.

Hamid, Abdul. 2015. "The Impact of Spin-Off Policy to The Profitability on Indonesian Islamic Banking Industry." Al-Iqtishad: Jurnal Ilmu Ekonomi Syariah VII (1): 117-26. https://doi.org/10.12816/0024787.

Haribowo, Ismawati. 2017. "The Indonesian Islamic Bank's Spin-off: A Study in Regional Development Banks." Al-Iqtishad: Journal of Islamic Economics 9 (1): 53-68. https://doi.org/10.15408/aiq.v9i1.4308.

Hilman, Iim. 2018. "Sharia Business Unit Spin-off: Strategic Development Model of Sharia Banking in Indonesia." In The 5th IBSM International Conference on Business, Management and Accounting, 856-67. Hanoi: Hanoi University of Industry. https://doi.org/10.54655/ijibfr.v2n2p1.

Pambuko, Zulfikar Bagus. 2019. "Kebijakan Spin-Off Dan Efisiensi Perbankan Syariah Di Indonesia." Ihtifaz: Journal of Islamic Economics, Finance, and Banking 2 (1): 21-38. https://doi.org/10.12928/ijiefb.v2i1.822.

Pambuko, Zulfikar Bagus, Nur Ichsan, and MB. Hendrie Anto. 2018. "Islamic Banks' Financial Stability and Its Determinants: A Comparison Study With Conventional Banks in Indonesia." Iqtishadia: Jurnal Kajian Ekonomi Dan Bisnis Islam 11 (2): 371-90. https://doi.org/10.21043/iqtishadia.v11i2.3346.

Pambuko, Zulfikar Bagus, Nurodin Usman, and Lilik Andriyani. 2019. "Spin-off and Social Funds' Productivity of Islamic Banking Industry in Indonesia." In First International Conference on Progressive Civil Society (ICONPROCS 2019), 7-10. Yogyakarta: Atlantis Press. https://doi.org/10.2991/iconprocs-19.2019.2. 
Poerwokoesoemo, Atman. 2016. "Kinerja Bank Konvensional Pasca Spin Off Unit Usaha Syariah." Jurnal Keuangan Dan Perbankan 12 (2): 145-64.

Republic of Indonesia. 2007. Undang-Undang Nomor 40 Tahun 2007 Tentang Perseroan Terbatas. Indonesia.

-__. 2008. Undang-Undang Nomor 21 Tahun 2008 Tentang Perbankan Syariah. Indonesia.

Rongiyati, Sulasi. 2015. "Pengembangan Perbankan Syariah Melalui Pelaksanaan Kewajiban Pemisahan Unit Usaha Syariah." Negara Hukum 6 (1): 65-78. https://doi.org/10.22212/jnh.v6i1.247.

Sarifudin, Mohammad, and Taufik Faturohman. 2017. "Spin-Off Efficiency Analysis of Indonesian Islamic Banks." Journal of Business and Management 6 (2): 192-202.

Sihombing, Novri Hasian, and M Rizal Yahya. 2016. "Pengaruh Kebijakan SpinOff, Beban Operasional Pendapatan Operasional (BOPO), Dana Pihak Ketiga (DPK), Dan Non Performing Financing (NPF) Terhadap Profitabilitas Perbankan Syariah Di Indonesia." Jurnal Ilmiah Mahasiswa Ekonomi Akuntansi 1 (2): 127-37.

Siswantoro, Dodik. 2008. "The Conversion Effects of Islamic Unit to Full Fledged System Islamic Banks in Indonesia." Australian Journal of Islamic Banking and Finance (AJIBF) 1 (2): 55-63.

___. 2014. "Analysis of Islamic Bank's Performance and Strategy After Spin-off as Islamic Full-Fledged Scheme in Indonesia." In Procedia - Social and Behavioral Sciences, 164:41-48. https://doi.org/10.1016/j.sbspro.2014.11.048.

Umam, Khotibul. 2010. "Peningkatan Ketaatan Syariah Melalui Pemisahan (Spin-off) Unit Usaha Syariah Bank Umum Konvensional." Mimbar Hukum 22 (3): 607-24. https://doi.org/10.22146/jmh.16239. 
Zulfikar Bagus Pambuko and Diesyana Ajeng Pramesti https://journal.walisongo.ac.id/index.php/economica 